ROCZNIKI TEOLOGICZNE

Tom LXVII, zeszyt $1-2020$

DOI: http://dx.doi.org/10.18290/rt20671-3

OLENA BOHUCHAROVA

\title{
UKRAINIAN VOLUNTEERS - NEW GENERATION OF SOCIAL WORKERS. PROBLEMS AND PERSPECTIVES
}

\begin{abstract}
The charity activity in warring Ukrainian society stipulated the interest to the social work volunteer's problem. Substantial changes also happened in the world psychology and social work: positive health psychology and positive approach to social work appeared; "emotional revolution" proceeds in the field of professional labor, the positive functioning of personality and to his/her well-being. Such initiatives and orientation were the methodological basis of the conducted research.

The sample of the research included 100 Ukrainian paramilitary volunteers. The interconnections between, the one side, the level of the emotional burnout, "the Dark triad" personality traits and, the another side, subjective and psychological well-being have been examined.

It turned out that the greater part of the tested persons is "within the limits of the norm" of burnout, but only in the first and second phases of emotional burnout - "tension" and "exhaustion". However the number of volunteers with high positive personality traits and low negative ones as "the Dark Triad" and vice versa low positive and high negative - in the third phase of emotional burnout - "resistance" in 1,5 times higher (64/42\%) accordingly. Paradoxical reverse interconnection was also found out high indexes of "the Dark Triad" and low - emotional burnout, positive connection of narcissism with the level of subjective well-being. The only fact that distinguishes two groups of volunteers is the best indexes of psychological well-being and conscientious as personality trait (Big-Five).

These data testify to the greater vulnerability for the negative consequences of burnout of high moral, "good" volunteers (low "Dark Triad").

The received results compel researchers to think: Does it really mean that "to be a best" paramilitary volunteer is not to have strong health but have significant level of emotional and occupational burnout in the conditions of war?
\end{abstract}

Key words: volunteers; "the Dark triad"; emotional burnout; well-being.

Olena Bohucharova, D.Sc. in Psychology, Associate Professor, Professor of the Department of Social-and-Humanitarian Disciplines and Professional Psychology, Luhansk State University of Internal Affairs named after E.O. Didorenko, Ukraine; address for correspondence: Donetska str. 1, 93404, Sievierodonetsk; e-mail: bogucharova_o@i.ua 


\section{RELEVANCE OF STUDIES}

Ukrainian paramilitary and military volunteers are the new phenomenon in the modern world of charitable activities. Updating of social initiatives of Ukrainians' military charity should be conceptualized in the aspect of, primarily, the resource of the voluntary paramilitary volunteers' activity. As a civilian, volunteer activity, in general, is tense but under the surrounding circumstances of military attacks and combatants' clashes, wounds and bleeding, death of soldiers its human cost is much more else raised. Therefore, in the context of military actions in which Ukrainian volunteers need "work" that activity becomes not only tense but a kind of highly negative, emotional destructive "labor", not only dangerous but mortally dangerous for those who help others in military sphere. However, for the volunteers in military conditions it is important, just the opposite, to experience emotional congruence as volunteer activities are aimed at achievement of a weal for other. That's why the feeling of emotional dissonance or inadequacy increases the risk of the appearance of burnout syndrome, reduces the job satisfaction of the volunteer in "helping" activity and provokes "departures" from volunteer activities.

In general, the results of almost all volunteer activity studies prove the fact that more than approximately two thirds $(2 / 3)$ of the surveyed volunteers suffer from the manifestations of "professional" deformation, somatic diseases, mental disorders, emotional burnout of 1-3 phases. ${ }^{1}$ This demonstrates the need to pay more attention to the mental health, emotional state and psychological well-being of paramilitary public activists.

This trend is supported by scientists. In particular, significant changes are taking place in the methodology of the research in world psychology and social work: positive health psychology and positive approach to social work has emerged, ${ }^{2}$ an "emotional revolution" continues in the professional work and emotional factors of labor are actualized as important resources for preserving and professional health. ${ }^{3}$ Also, new emphasis has been placed on

\footnotetext{
${ }^{1}$ T.D. RAWLINS, A. HousKA, "Motivations and satisfactions of the hospice of Wichita volunteer: implications for marketing," American Journal of Hospice and Palliative Care (1986), 3 (4): 15-18.

2 M.E.P. Seligman, T.A. Steen, N. Park, "Positive Psychology Progress. Empirical Validation of Interventions," American Psychologist (2005), 2: 410-421; G.V. CAPRARA, "Positive orientation: Turning potential into optimal functioning," The European Health Psychologist (2009), 11: $46-48$.

3 "Emotions at work: Theory, research and applications for management," ed. R.L Payne., C.L. Cooper (Chichester, UK: John Wiley and Sons, 2006), 22; U.R. HulShEGER, J.W. LaNG,
} 
studying personal factors maintaining that appeal to the positive functioning of a person ${ }^{4}$.

The intensity of the latter actually depends on the feeling of the subjective and psychological well-being of the working person. The change of the emphasis and the shift of attention to the study of the positive aspects of occupational health is accompanied by an equal increase in the number of studies of the positive consequences for the working person. As to negative ones, among them, an important place belongs to the emotional burnout. ${ }^{5}$

In the psychological literature of the $\mathrm{XX}-\mathrm{XXI}^{\text {th }}$ century the phenomenon of emotional burnout has a fairly long history. The first empirical publications gradually changed into conceptual assumptions analyzing the causes, structure, symptoms, and effects of the syndrome. These are the concepts of emotional burnout (V.V. Boyko, K. Maslach ${ }^{6}$ ); the factor and procedural models of burnout (E. Aronson, D. Dierendonk, D. Kafry, E. Pines H. Siksma, V. Shaufeli ${ }^{7}$ ); the theory of psychological stress (G. Selye ${ }^{8}$ ). According to generally accepted approaches emotional burnout is interpreted as a threedimensional syndrome characterized by emotional exhaustion, depersonalization and reduction of professional accomplishment. ${ }^{9}$

In the study of the burnout syndrome, scientists first paid more attention to the external factors, but it is becoming increasingly clear that external and organizational factors are secondary and personal one's are more significant.

G.W. MAIER, "Emotional labor, strain, and performance: Testing reciprocal relationships in a longitudinal panel study," Journal of Occupational Health Psychology (2010), 15(4): 505-521.

${ }^{4}$ C. Fullugar, E.K. Kelloway, "New Directions in Positive Psychology: Implications for a Healthy Workplace," in: Contemporary occupational health psychology: Global perspectives on research and practice, ed. J. Houdmont, S. Leka and R.R. Sinclair (Chichester, UK: John Wiley \& Sons, Ltd., (2012), 2: 146-161.

5 H.J. FreudenBerger, "Staff Burnout," Journal of Social Issue (1974), 30(1): 159-65; C. MASLACH, M.P. LEITER, "Understanding the burnout experience: Recent research and its implications for psychiatry," World Psychiatry (2016), 15(2): 103-111; N. VodOPYANOVA, Y.S. STARCHENKOVA, "Burnout syndrome: diagnosis and prevention," 2nd ed. (SPb.: Peter, 2008), 336.

${ }^{6}$ V.V. Bочко, "The energy of emotions in communication: a look at oneself and on others," (Yaroslavl: Avers Press, 2004): 338; C. MASLACH, "Burnout: The cost of caring” (NY: PrenticeHall, 1982), 289.

${ }^{7}$ A.M. Pines, E. Aronson, D. Kafry, "Burnout. From Tedium to Personal Growth," (NY: Free Press, 1981), 345-356; D.V. Dierendonck, W.B. Schaufeli, H.J. Siksma, "Burnout among general practitioners: a perspective from equity theory," Journal of Social and Clinical Psychology (1994), 13 (1): 96-108.

${ }^{8}$ H. Selye, "Stress without distress" (Moscow: Progress; 1998), 125.

${ }^{9}$ Definition of BURNOUT. [https://www.merriam-webster.com/dictionary/burnout] (accessed 22 June, 2019). 
As studies of positive psychology have shown these are, they which provide a feeling of well-being to a person. ${ }^{10}$

Recently researchers of the burnout personal factors problem are increasingly paying attention to one of the negative aspects of this syndrome: under the influence of emotional experiences not only the emotional state of a person who performs his professional or public duties changes but also irreversible deformations of a personality with whom the specialist contacts appear (volunteers and recipients of assistance). Such behavior leads to the professional deformation of a volunteer and also makes impossible a personal growth of the "client" of the social initiative. That's why we advocate for more methodological approaches to explore personality traits of burnout in military volunteers' service organizations.

Various personality factors are linked to low or high burnout risks. For example, among personality traits we have too little in-depth knowledge about the influence of negatively connoted traits (e.g., narcissism for social identity building) as well as about some aspects that are generally seen as positive (e.g., manipulation). Researchers and practitioners alike have much more focused their attention on positive personality traits and processes ex plain in the volunteer movement. Recently, however, perhaps in the wake of various scandals involving misbehavior of leaders of blogs and who are having a profile on a social portal or rank-and-file employees (e.g., Ukrainian presidential elections scandal and official-organizations volunteers scandal), more attention has gone out to less positive or even dark sides of organizational functioning of volunteers' services. As to negative traits and emotions (e.g., distrust, envy) in interaction processes it is necessary to stress that apart from standard problems associated with paramilitary volunteers' activity, activists who are working with victims of the ATO / OUF, in addition, accumulate significant financial resources. In the case of the demonstration of "dark features" it is unlikely that a paramilitary volunteer will be a good "lawyer" of the ordinary people.

Consequently, the impact of dark-side traits such as "the Dark triad" of Narcissism, Machiavellianism, and psychopathy as well as negative interactions between leader of paramilitary and military volunteers and some of them as followers in the volunteer organization is becoming increasingly evident.

\footnotetext{
${ }^{10}$ E.L. NosenKo, N.V. Hrysenko, "Novyi pidhid do doslidjennya 'tsinnostey u diyi: perevahy, dosvid, zastosuvannya dlya vyvchennya chynnykiv emotsiynoho vihorannya pedahoha," Zbirnyk naukovykh prats KPNU imeni Ivana Ohiyenka. Problemy suchasnoyi psykhologiyi (2010), 10: 490-500.
} 
The concept of "the Dark triad" of personality traits ${ }^{11}$ consists of three characteristics: narcissism, Machiavellianism and psychopathy. Each characteristic has its own content. One of the essential issues in the study of the triad is the General factor that underlies all three characteristics. The hypothetical general factors are: honesty, high self esteem, emotional coldness, low friendliness, and inclination for deception, non-clinical psychopathy, high self-esteem etc. In recent studies a negative relationship with the Dark triad indicators of dispositional traits has been discovered: emotional intelligence, agreeableness (the Big five), honesty (model NEGASO). Narcissism as a characteristic describes the desire for leadership, demonstrative behavior and the "use" of other people, a sense of self-importance or grandiosity. Psychopathy as a component of the Dark triad is characterized by low anxiety, impulsivity, disregard of social norms, the low level of life satisfaction, and most importantly, non-constructive professional adaptation. ${ }^{12}$ Machiavellianism is a manipulative behavioral tactics, cynicism, pragmatism and emotional coldness. Machiavellist often focuses only on himself and not on the communication with a partner. This kind of man is smart, brave, ambitious but stubborn and selfish.

Equally important is the study of psychological well-being and satisfaction in the volunteer organizations. ${ }^{13}$ The psychological well-being construct has been explored since the 1960s of the XX-the century. Initially, it was presented as a balance between positive and negative affect which is a state of happiness. (One formulation, traceable to Bradburn's (1969) early work, distinguished between positive and negative effects on the balance between the two.) Subsequently, various researchers have identified many new indicators and formulated various approaches. In most of these approaches such close concepts as happiness, satisfaction with life, positive affect are being explored. The most famous among them is the multidimensional model of the well-being. ${ }^{14}$ There are six distinct components of positive psychological

${ }^{11}$ D.L. Paulhus, K.M. Williams, "The Dark Triad of personality: Narcissism, Machiavellianism and psychopathy," Journal of Research in Personality (2002), 36 (6) : 556-563.

${ }^{12}$ L.A. Seibert, J.D. Miller, L.R.Few, A. Zeichner, D.R. LynAm, "An Examination of the structure of self-report psychopathy measures and their relations with general traits and externalizing behaviors." Personality Disorders: Theory, Research, and Treatment (2011), 2 (3): 193-208.

${ }^{13}$ E. DEINER, International differences in well-being, (N.Y.: Oxford University Press, 2010), 210; S.G. EKIMOVA, Volonterskaia deiatel 'nost' kak resurs lichnostno-professional'nogo razvitiia budushchikh spetsialistov po sotsial'noi rabote, Diss. kand. ped. nauk. [Volunteering as a resource for personal-professional development of the future of social work. $\mathrm{PhD}$ (pedagogy) diss.]. (Khabarovsk, 2010), 226.

${ }^{14}$ C. RYFF, "The Structure of Psychological Well-Being Revisited," Journal of Personality and Social Psychology (1995), 69 (4): 719-727. 
functioning (autonomy, environmental mastery, personal growth, positive relations with others, purpose in life, self-acceptance).

Thus, there are, obviously, little researches aimed at studying psychological variables of a person who performs charitable activities in the context of a military conflict.

The purpose of this article is to examine the possible relationships between burnout and the subjective and psychological well-being as the level of volunteers" "job" satisfaction and to define individual determinants - not only positive but negative traits - "the Dark triad" of Narcissism, the Machiavellianism, Psychopathy that are also important stressors for volunteers depending on certain personality' peculiarities and also para-military or military "organizational working" conditions.

To determine the characteristics of this relationship an empirical study was conducted on the basis of the centers "Aid to the Dnieper" in the city of Dnipro and "Vostok SOS" in the town of Sievierodonetsk. The sample consisted of 100 people - volunteers (women and men). The age of the surveyed is from 23 to 45 years, the experience of military social activity is from 2 to 4 years.

Research methods: "Maslach Burnout Inventory" (MBI) was used as one of the most prominent and most widely scales for measurement of burnout. "Boyko's Emotional Burnout Inventory" (BEBI) was used too. It contains 84 questions which are grouped into three scales and are divided into four subscales accordingly making it possible to diagnose the formation of each of the three burnout phases: stress, resistibility, and exhaustion. The total score of four subscales allows diagnosing the presence and extent of the severity of the symptoms (signs) characteristic for each burnout phase. Personality negative characteristics were diagnosed by "the Short Dark Triad" questionnaire (SDT) by D. Jones and D. Paulhus ${ }^{15}$ which evaluates three properties: narcissism, the Machiavellism and psychopathy. It is a diagnostic tool consisting of 27 statements combined in 3 subscales. The study was based on translated "Short Dark Triad" questionnaire into Ukrainian and adapted for usage by military volunteers. Personality characteristics extraversion; agreeableness; consciousness; neuroticism; openness to experience were diagnosed by the Big-five taxonomic Inventory by L. Goldberg, adapted to the Ukrainian culture by L.F. Burlachuk and D.K. Korolev. Besides, Eysenck Personality Questionnaire by G. Eysenck was used too as famous instrument

${ }^{15}$ D.N. Jones, D.L. PAulus, "Introducing the Short Dark Triad (SDT): A Brief Measure of Dark Personality Traits,” Assessment (2014), 21(1) : 28-41. 
of multifactorial assessment. This study analyzed the level of volunteers' "job" satisfaction and therefore, utilized subjective and psychological wellbeing scales: "Satisfaction with Life Scale" (SWLS) by E. Diener et al., a slightly newer scale, developed in 2008 by Y.N. Osin, D.A. Leontyev and "Scales of Psychological Well-Being" (PWB) C. Ryff adapted to the Ukrainian culture by O.M. Znanetska.

Methods of processing. Data processing was performed using the statistical package of IBM SPSS Statistics 21. Mean values for the whole questionnaire and its separate parts were calculated for each individual.

\section{RESULTS AND THEIR ANALYSIS}

The study by the method of the Maslach Burnout Inventory (MBI) showed the following results. In general within the total sampling, the average rate of burnout is as follows: as to emotional exhaustion, $-46,71$ points, as to depersonalization $-36,29$ points, and as to reduction of professional accomplishment - 73,67 points. For the depersonalization burnout components, the index is 36,29 points of cynicism and detachment in relation to the organization where the person works and to its "clients" indicating that the index is not formed. Almost $60,4 \%$ of the subjects reported a high or very high total burnout rate within burnout component of reduction of professional accomplishment. It means that the signs of a traumatic experience symptom are diagnosed in $60,4 \%$ of sample. The sense of reduction of professional accomplishment is described as confidence in individual's own incompetence, and his own self-inefficiency.

The study by the method of the Boyko's Emotional Burnout Inventory showed the following results. In particularly, within the total sampling, the average rate of burnout is as follows: for the tension phase $-35,4$ points, for the resistance phase $-52,3$ points, which indicates the process of data generation of the two features. For the exhaustion phase, the index is 33.7 points resistibility, indicating that the index is not formed.

As many as $48,47 \%$ of the surveyed volunteers reveal signs of situational and personal anxiety which is the most important symptom of the first phase of burnout. Among them, 13,7\% of the respondents have already formed sign of burnout, and in $22,5 \%$ of the respondents this form of a sign is still being formed. 
In order to establish the differences in a data of burnout, depending on personality determinants, both groups were tested with "the Short Dark Triad" questionnaire, the Big-five taxonomic Inventory, Eysenck Personality Questionnaire.

After this, paramilitary volunteers were divided into two groups - those who are having high "Dark Triad" subjects (group 1) and those who are having low "Dark Triad" subjects (group 2). Intergroup differences were calculated for the separate scores for each of the 3 subscales of the questionnaire. Detailed data are shown in Table 1.

For all three factors SDT the mean value was higher for those already having high "Dark Triad" than for those who are having low "Dark Triad" subjects. Among three factors the mean value of Machiavellianism was higher. Statistically significant differences between groups of those who are having high "Dark Triad" subjects (group 1) and those who are having low "Dark Triad" subjects (group 2) occurred in three factors: Machiavellianism ( $\mathrm{p}<0,001)$, Narcissism ( $<<0,001)$, Psychopathy $(\mathrm{p}<0,001)$.

Table 1. Intergroup differences in score of those who are having high "Dark Triad" subjects (group 1) and of those who are having low "Dark Triad" subjects (group 2)

\begin{tabular}{|c|c|c|c|c|c|}
\hline $\begin{array}{c}\text { Factor } \\
\text { SDT }\end{array}$ & & $\begin{array}{c}\text { Persons who } \\
\text { are having } \\
\text { high "Dark } \\
\text { Triad" }\end{array}$ & $\begin{array}{l}\text { Persons who } \\
\text { are having low } \\
\text { "Dark Triad" }\end{array}$ & $\mathrm{T}$ & $\mathrm{p}$ \\
\hline \multirow{2}{*}{ Machiavellianism } & $\mathrm{M}$ & 4,08 & 2,98 & \multirow{2}{*}{3,924} & \multirow{2}{*}{0,001} \\
\hline & SD & 8,679 & 9,605 & & \\
\hline \multirow{2}{*}{ Narcissism } & $\mathrm{M}$ & 4,37 & 3,07 & \multirow{2}{*}{5,260} & \multirow{2}{*}{0,001} \\
\hline & SD & 10,596 & 13,675 & & \\
\hline \multirow{2}{*}{ Psychopathy } & $\mathrm{M}$ & 3,88 & 2,08 & \multirow{2}{*}{5,810} & \multirow{2}{*}{0,001} \\
\hline & SD & 11,350 & 14,976 & & \\
\hline
\end{tabular}

Legend: M - mean; SD - standard deviation; $\mathrm{t}$ - Student's t-test; $\mathrm{p}$ - significance of differences

The analysis of intergroup differences revealed statistically significant differences in burnout components and in the most important symptoms of the first - third phases, and in total burnout index. Estimation of the level of burnout phases for each of the subjects gave the following results. The stress phase is being formed or is already formed in $48 \%$ of the respondents. A percentage of the total number of persons in the group of volunteers contrasting the severity of signs of the "the Dark Triad" and the mean value are shown in Table 2. 
According to the results of the Maslach Burnout Inventory (MBI) the group of surveyed "volunteers" with a low and high rate of the "Dark Triad" differ most significantly among themselves in the number of people in the group and in the burnout components - total 74 via 26 persons. Among the subjects with a low Dark Triad the number of persons with a high level of burnout and already formed (symptomatic) phase is greater than among those with high Dark Triad scores.

On the average, in the surveyed group phases of the "stress" and "exhaustion" are not else formed and the resistance phase is in the formation in both groups. However, if all volunteers are divided into three groups depending on their personal burnout score: "within normal limits", "forming phase" and "formed phase", then the total number with a low "Dark Triad" related to the "forming " and "formed" phases of the symptom in the phases of "stress" and "exhaustion" is approximately $42 \%$.

Table 2. Intergroup differences in score of burnout phases and the most important formed burnout symptoms between those who are having high "Dark Triad" subjects (group 1) and those who are having low "Dark Triad" subjects (group 2)

\begin{tabular}{|c|c|c|c|c|c|}
\hline \multirow{3}{*}{ Scale indicator } & \multirow{3}{*}{$\begin{array}{l}\text { Index of the stress } \\
\text { phase } \\
\text { is being formed or } \\
\text { already formed } \\
\text { and symptoms of } \\
\text { burnout }\end{array}$} & \multicolumn{4}{|c|}{$\begin{array}{l}\text { Total number of persons in the group of volunteers } \\
\text { contrasting the severity of signs of "the Dark Triad" \% }\end{array}$} \\
\hline & & \multicolumn{2}{|c|}{$\begin{array}{c}\text { Group } 1 \\
\text { Low "Dark Triad" } \\
(\mathrm{N}=74)\end{array}$} & \multicolumn{2}{|c|}{$\begin{array}{c}\text { Group } 2 \\
\text { High " Dark Triad" } \\
(\mathrm{N}=26)\end{array}$} \\
\hline & & M & $\%$ & M & $\%$ \\
\hline \multirow{3}{*}{ MBI } & High & 85,4 & 33,5 & 70,8 & 10 \\
\hline & Moderate & 46,7 & 20 & 42,4 & 11 \\
\hline & Low & 22,2 & 46,5 & 20,2 & 79 \\
\hline \multirow{3}{*}{$\begin{array}{l}\text { Boyko's } \\
\text { Emotional } \\
\text { Burnout } \\
\text { Inventory }\end{array}$} & $\begin{array}{l}\text { Within normal } \\
\text { parameters }\end{array}$ & $33,2 \pm 17,51$ & 51 & $54,74 \pm 16,67$ & 79 \\
\hline & $\begin{array}{l}\text { Forming burnout } \\
\text { phases }\end{array}$ & $51.70 \pm 16,78$ & 30,5 & $45,85 \pm 18,40$ & 13 \\
\hline & $\begin{array}{l}\text { Already formed } \\
\text { burnout phases }\end{array}$ & $55,10 \pm 17,02$ & 18,5 & $53,75 \pm 16,78$ & 8 \\
\hline
\end{tabular}


At the same time, volunteers from this group with indicators "outside the norm" in the "resistance" phase make up the majority $-63,5 \%$ of the total number of the surveyed persons. These data indicate the high emotional burnout of volunteers with low score of negative traits - "the Dark Triad" while the number of volunteers with a high "Triad" in the same phases is three times lower in their group and four times lower in comparison with the group with a low "Triad" $-11 \%$ respectively. In the "resistance" phase they are only one-third (33\%), and in the "exhaustion" phase they are not represented at all.

In the group of volunteers with a low "Dark Triad" the sum of the "forming" and "formed" symptom in all 12 symptoms exceeds the known 30 $\%$ limit "beyond the norm" while in the group of volunteers with a high "Dark Triad" is still approaching to this level. Coefficients of the internal consistency of the scales in both groups ranged from 0,65 to 0,79 . Thus, the distribution of burnout severity differed significantly between three subscores phases $(p<0,001)$. In order to establish the differences in an individual determinants of burnout we analyzed differences (by t-test) between the mean values of all the Big-Five personality variables. Detailed scores are presented in Table 3.

Table 3. Mean values of the Big-Five personality variables between those who are having high "Dark Triad" subjects (group 1) and those who are having low "Dark Triad" subjects (group 2)

\begin{tabular}{|c|c|c|c|c|c|}
\hline \multirow{2}{*}{ Groups } & \multicolumn{5}{|c|}{ Mean values of trait variables } \\
\cline { 2 - 6 } & Extraversion & Agreeableness & $\begin{array}{c}\text { Conscientio } \\
\text { usness }\end{array}$ & Neuroticism & $\begin{array}{c}\text { Openness to } \\
\text { experience }\end{array}$ \\
\hline $\begin{array}{c}\text { Group 1 } \\
(\mathrm{N}=74) \\
\text { Low "Dark } \\
\text { Triad" }\end{array}$ & 23,5 & 33,5 & 29,6 & 16,1 & 32,4 \\
\hline $\begin{array}{c}\text { Group 2 } \\
\text { (N = 26) } \\
\text { High "Dark } \\
\text { Triad" }\end{array}$ & 21,6 & 28,5 & 24,0 & 25,2 & 21,7 \\
\hline $\begin{array}{c}\text { Significance } \\
\text { of differences } \\
\text { by t-test: }\end{array}$ & $\mathrm{p}<0,001$ & $\mathrm{p}<0,05$ & $\mathrm{p}<0,05$ & $\mathrm{p}<0,01$ & $\mathrm{p}<0,01$ \\
\hline
\end{tabular}

Table 3 shows statistically significant differences (by t-test) between the mean values of all the Big-Five personality variables for 1 and 2 groups of 
volunteers. As evident from Table 3, the participants of the group with low "Dark Triad" scores have higher scores on extraversion, agreeableness, conscientiousness, openness to experience and lower neuroticism. According to R. McCrae, P. Costa and co-authors (2005) the five-factor model exhibits universal aspects of human nature. As a result, the individuals with higher scores on that one universal aspect are much more capable to adapt to external restrictions and constraints, they are resourceful in adapting to novel situations.

In spite of this the results of polling 100 paramilitary volunteers show that about two thirds of working volunteers show prominent features of high level burnout. This is combined with a number of total high score of positive personality traits and features of behavior and total low score of negative ones such as "Dark Triad". Above all those paramilitary volunteers who are having high "Dark Triad" as subjects had the average score of burnout.

Thus, the results obtained indicate that the emotional state of the majority of surveyed volunteers with a low "Dark Triad" does not contribute to the maximum effectiveness of their charitable paramilitary volunteer' activity. Meanwhile, their group has high scores of positive personality variables and good adaptive capability to external conditions. As our previous studies showed, volunteers working with ATO victims are different from volunteers who do not have such experience in their index of psychological well-being and emotional burnout. These differences are also manifested in total high score of extraversion, openness to experience, agreeableness and low neuroticism. But they are under high burnout risks.

On the contrary, people who have a "dark features" profile are less autonomous, less responsible, worse cope with the tasks of everyday life and are less tolerant and caring towards other people in their volunteers' activity. But they aren't under high burnout risks.

Based on these data, General characteristics of the burnout volunteers with low "Dark Triad" scores were underlined. They are reflected in the form of internal vulnerability, pain, inability to correctly differentiate environmental stimuli, feeling of helplessness. In keeping with the metaphor it is "a person with a naked skin." That is, the connection to the state of the client in group 1 increases the occurrence of the emotional burnout. In general, in group 2 with high "Dark Triad" scores of introversion, low commitment, medium impulsiveness, emotional stability and expressiveness are very high. Those all are observed in persons with "dark features" but the level of their burnout is much below.

The Pearson's correlation analysis in the group with "dark features" showed the following results. The paramilitary and "military" volunteers 
have strong positive correlation connections between phases of burnout and personality traits. For example, under the Pearson's correlation coefficient in the group with low "dark features" there are links between the phase "tension" and conscientiousness $(\mathrm{r}=0,198 * *)$, repressiveness $(\mathrm{r}=0,231 *)$, emotional liability $(\mathrm{r}=0,237 *)$, and neuroticism $(\mathrm{r}=0,259 *)$. This suggests that the polling volunteers experience stress response to a normal situation, they have frequent mood swings, irritability and insufficient self-regulation level. At the same time, it was established in volunteers with a high rate of "dark features" a moderate positive correlation between "emotional exhaustion" and neuroticism $(\mathrm{r}=0,199 *)$ between the "resistance" $(\mathrm{r}=0,232 *)$ and symptoms of "depersonalization" $(\mathrm{r}=0,346 *)$, also "tension" or "reduction of personal accomplishment" and repressiveness $\left(r=0,256^{*} ; r=0,299^{*}\right)$. The density of the relations between some phases of burnout and neuroticism may indicate to the deeper nature of the overall tension of volunteers with negative "dark features" that influence the effectiveness of their "helping" activities in combatant war.

However, in general, volunteers with a low regulatory such as the dark triad of Narcissism, Machiavellianism, and psychopathy have a higher level of formation of such personal characteristics as: kindness, diplomacy, restraint, interpersonal skills, ability to maintain positive relations with others, the normativity of behavior and higher levels of psychological well-being $(\mathrm{t}=$ from 3,2 to 5,7 at $\mathrm{p}<0,05, \mathrm{p}<0,01, \mathrm{p}<0,001)$.

Interpreting these data, it can be stated that dark triad-free people have a well-satisfied need for "job", accordingly the average and high level of "job" satisfaction. The analysis of the subjective and psychological well-being of volunteers showed the following results. Detailed data are shown in Table 4.

Table 4. The correlation between indicators of all the Big-Five personality variables, the subjective and psychological well-being and "Dark Triad" features in the surveyed group

\begin{tabular}{|c|c|c|c|c|c|c|c|}
\hline SScales & $\begin{array}{c}\text { Extra } \\
\text { version }\end{array}$ & $\begin{array}{c}\text { Agreeable- } \\
\text { ness }\end{array}$ & $\begin{array}{c}\text { Conscien- } \\
\text { tiousness }\end{array}$ & Neuroticism & $\begin{array}{c}\text { Openness } \\
\text { to } \\
\text { experience }\end{array}$ & SWILS & PWB \\
\hline $\mathrm{MN}$ & 0,148 & $-0,336^{*}$ & $0,233^{*}$ & 0,192 & 0,176 & $0,390^{* *}$ & $0,255^{*}$ \\
\hline $\mathrm{NM}$ & 0,244 & $-0,354^{*}$ & 0,0216 & 0,078 & 0,236 & 0,087 & $0,458^{*}$ \\
\hline $\mathrm{p} \mathrm{P}$ & 0,094 & 0,029 & $0,247^{*}$ & $-0,307^{*}$ & 0,080 & $-0,178$ & 0,094 \\
\hline
\end{tabular}

Legend: * $\mathrm{p}<0,05,{ }^{* *} \mathrm{p}<0,01 * * * \mathrm{~N}-$ nonclinical Narcissism, $\mathrm{M}-$ Machiavellianism, $\mathrm{P}$ - nonclinical Psychopathy; SWILS - "Satisfaction with Life Scale"; PWB - "Scales of Psychological Well-Being" 
The average score on the questionnaire of well-being by E. Diener in the subsample with low "Dark Triad" is 25,6 $(\sigma=5,24)$, and with a high one $19,9(\sigma=4,35)$. The results reflecting social aspects of a well-being are close enough to the standard ones. According to the results of the correlation analysis between symptoms and phases of burnout and personality features, moderate positive relationship of narcissism with a scale of life satisfaction according to E. Diener is $r=0,390, p<0,001$, narcissism and Machiavellianism with the integral indicator of psychological well-being according to C. Ryff $-\mathrm{r}=0,255, \mathrm{p}<0,001 ; \mathrm{r}=0,458, \mathrm{p}<0,05$, the correlation of psychopathy with symptoms of depersonalization $r=0,364, p<0,05$ according to Pearson were obtained. As to the results of correlation analysis the relationships between "the Dark Triad" and symptoms of burnout as well as an integral indicator of psychological well-being is in the range from 0,354 to $+0,458$.

\section{CONCLUSIONS}

The results of the study examined the relationship between "emotional burnout" and the subjective and psychological well-being as the level of volunteers" "job" satisfaction and individual determinants - positive (the Big-Five personality variables) and negative traits ("the Dark triad" features") that are also important stressors for volunteers depending on certain personality' peculiarities and also paramilitary or military "organizational working" conditions.

The main result of our study was finding that of 100 paramilitary volunteers about two thirds of them show high level burnout (the phase of emotional burnout - "resistance") (64\%). This is combined with a number of total high score of positive personality traits and peculiarities of their behavior and also total low score of the negative one such as "Dark Triad". Those paramilitary volunteers with high "the Dark Triad" had the average score of burnout (64/42\%). The number of "burned out" volunteers with a low "the Dark triad" is more than in the same volunteers with a high rate of "the Triad". The unexpected result is a moderate positive relationship of Machiavellianism with the integral indicator of psychological well-being according to K. Riff, and narcissism with a scale of life satisfaction according to E. Diener, narcissism and the relationship of psychopathy with symptoms of depersonalization. These data can be explained by the fact that narcissism as 
a personality feature is characterized by a tendency to self-glorification; Machiavellism - by a tendency to demonstrate the success and dominance; and psychopathy and depersonalization are special personality' constructs. It was stated that volunteers with low levels of "the Triad" in comparison with high rates have more expressed positive personal characteristics (R. McCrae, P. Costa, G. Eysenck). In addition, in volunteers with high "dark features" and the close relationship of neuroticism the low level of burnout may indicate to a special nature of the common tension at war influencing the effectiveness of "helping" activities.

The obtained results do not only change common approaches to the study but make researchers think about the problem what "humanitarian price" of negative features of a personality is at war. Further studies are needed to involve representative samples of clarifying the role of "the dark features" in the subjective experience of emotional burnout and psychological well-being at war.

Thus, summing up, one may ask two questions: Does it really mean that to be "a bad" paramilitary volunteer is to have stronger health and high selfeffectiveness? And vice versa. Does it really mean that "to be a best" paramilitary volunteer is not to have strong health but have significant level of emotional and occupational burnout in the conditions of war?

\section{REFERENCES}

BOYKO, V.V. The energy of emotions in communication: a look at oneself and on others. Yaroslavl: Avers Press, 2004.

CAPRARA, G.V. "Positive orientation: Turning potential into optimal functioning." The European Health Psychologist (2009), 11: 46-48.

Definition of BURNOUT [https://www.merriam-webster.com/dictionary/ burnout] (accessed 22 June, 2019).

DEINER, E. International differences in well-being. N.Y.: Oxford University Press, 2010.

Dierendonck, D.V., Schaufeli, W.B., Siksma, H.J. "Burnout among general practitioners: a perspective from equity theory," Journal of Social and Clinical Psychology (1994), 13 (1): 96-108.

EкIMOvA, S.G. Volonterskaia deiatel'nost" kak resurs lichnostno-professional'nogo razvitiia budushchikh spetsialistov po sotsial'noi rabote,". Diss. kand. ped. nauk. [Volunteering as a resource for personal-professional development of the future of social work. $\mathrm{PhD}$ (pedagogy) diss.]. Khabarovsk, 2010.

Emotions at work: Theory, research and applications for management. Ed. R.L. Payne, C.L. Cooper. Chichester, UK: John Wiley and Sons, 2006.

Hulsheger, U.R., LANG, J.W., Maier, G.W. "Emotional labor, strain, and performance: Testing reciprocal relationships in a longitudinal panel study." Journal of Occupational Health Psychology (2010), 15(4): 505-521. 
FREUDENBERGER, H.J. “Staff Burnout.” Journal of Social Issue (1974), 30 (1):159-65.

Fullugar, C., Kelloway, E.K. "New Directions in Positive Psychology: Implications for a Healthy Workplace." In: Contemporary occupational health psychology: Global perspectives on research and practice. Ed. J. Houdmont, S. Leka, R.R. Sinclair (146-161). Chichester, UK: John Wiley \& Sons, Ltd., 2012.

Jones, D.N., PAulus, D.L. "Introducing the Short Dark Triad (SDT): A Brief Measure of Dark Personality Traits." Assessment (2014), 21(1): 28-41.

KORNEEVA, E.L. The main directions of research volunteer activities [Elektronnyi resurs]. Psikhologicheskaya nauka i obrazovanie PSYEDU.ru [Psychological Science and Education PSYEDU.ru], 2015, vol. 7, no. 1. Available at: http://psyedu.ru/journal/2015/n1/Korneeva. phtml (Accessed dd.mm.yyyy). (In Russ., Abstr. in Engl.).

MaSlaCh, C. Burnout: The cost of caring. NY: Prentice-Hall, 1982.

Maslach, C., Leiter, M.P. "Understanding the burnout experience: Recent research and its implications for psychiatry." World Psychiatry (2016), 15(2): 103-111.

Nosenko, E.L., Hrysenko, N.V. "Novyi pidhid do doslidjennya 'tsinnostey u diyi: perevahy, dosvid, zastosuvannya dlya vyvchennya chynnykiv emotsiynoho vihorannya pedahoha," Zbirnyk naukovykh prats KPNU imeni Ivana Ohiyenka. Problemy suchasnoyi psykhologiyi (2010), 10: 490-500.

Pines, A.M., Aronson, E., Kafry, D. Burnout. From Tedium to Personal Growth (345-356). NY: Free Press, 1981.

Paulhus, D.L., Williams, K.M. "The Dark Triad of personality: Narcissism, Machiavellianism and psychopath." Journal of Research in Personality (2002), 36(6): 556-563.

RAwLINS, T.D., HousKA, A. "Motivations and satisfactions of the hospice of wichita volunteer: implications for marketing." American Journal of Hospice and Palliative Care (1986), 3(4): $15-18$.

RYFF, C. "The Structure of Psychological Well-Being Revisited.” Journal of Personality and Social Psychology (1995), 69(4): 719-727.

Seligman, M.E.P., Steen, T., Park, A.N., "Positive Psychology Progress. Empirical Validation of Interventions," American Psychologist (2005), 2: 410-421.

SElYe, H., Stress without distress. Moscow: Progress, 1998.

Seibert, L.A., Miller, J.D., Few, L.R., Zeichner, A., LynAM, D.R. “An Examination of the structure of self-report psychopathy measures and their relations with general traits and externalizing behaviors." Personality Disorders: Theory, Research, and Treatment (2011), 2(3): 193-208.

Vodopyanova, N., Starchenkova, Y. Burnout syndrome: diagnosis and prevention. 2nd ed. SPb.: Peter, 2008.

\section{UKRAIŃSCY WOLONTARIUSZE - NOWE POKOLENIE PRACOWNIKÓW SOCJALNYCH. PROBLEMY I PERSPEKTYWY}

\section{STRESZCZENIE}

Działalność charytatywna w społeczeństwie ukraińskim, które jest w stanie wojny, zakłada zainteresowanie kwestią pracy wolontariuszy socjalnych. W dziedzinie psychologii i pracy socjalnej także nastąpiły poważne zmiany - pojawiła się pozytywna psychologia zdrowia i pozy- 
tywne nastawienie do pracy socjalnej. „Rewolucja emocjonalna” następuje w zakresie pracy zawodowej, prawidłowego funkcjonowania osobowości i dobrostanu jednostki. Takie inicjatywy i nastawienie legły u podstaw prezentowanych badań.

Próba badawcza obejmowała 100 ochotników ukraińskich grup paramilitarnych. Zbadane zostały powiązania pomiędzy stopniem wypalenia emocjonalnego, cechami osobowości należącymi do „ciemnej triady” a subiektywnym poczuciem zadowolenia i dobrostanem psychicznym.

Okazało się, że większość badanych osób znajduje się „w granicach normy” wypalenia emocjonalnego, ale tylko w jego pierwszej i drugiej fazie, tj. „napięcia” i „wyczerpania”. Stosunek liczby ochotników o dużym nasileniu pozytywnych cech osobowości i tych o niskim nasileniu cech negatywnych należących do „ciemnej triady” i na odwrót - tych o niskim poziomie cech pozytywnych i wysokim poziomie cech negatywnych, będących w trzeciej fazie wypalenia emocjonalnego - wynosi 1,5, tzn. 64 / 42\%. Paradoksalnie, wykazano także odwrotną korelację pomiędzy wysokimi wynikami w zakresie „ciemnej triady” a niskim wypaleniem emocjonalnym oraz dodatnią korelację pomiędzy narcyzmem a poziomem subiektywnego poczucia zadowolenia. Jedyny element, który różnicuje dwie grupy ochotników, to najwyższe uzyskane wyniki w zakresie dobrostanu psychicznego oraz sumienność jako cecha osobowości (wielka piątka).

Dane te świadczą o większej podatności na negatywne konsekwencje wypalenia wśród „,dobrych” ochotników o wysokim morale (niskie wyniki w zakresie „ciemnej triady”).

Uzyskane wyniki skłaniają badaczy do odpowiedzi na pytanie, czy aby być „najlepszym” ochotnikiem formacji paramilitarnej, nie trzeba mieć dobrego zdrowia, lecz być w stanie znacznego wypalenia emocjonalnego i zawodowego w warunkach wojny?

Słowa kluczowe: wolontariusze; „ciemna triada”; wypalenie emocjonalne; dobrostan. 